
link by the ainplo axpadiont of uoing ce ratio per. Conbex

The Bigital control cheand is coupled to the antwrt chrough a "combr", wich containe an if boden ad

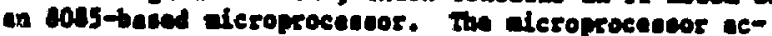

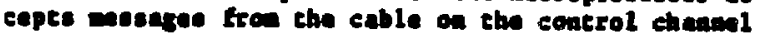

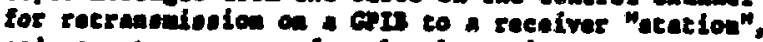

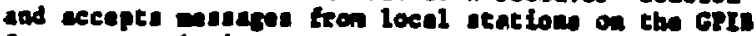

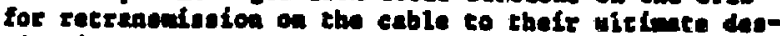

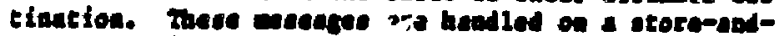
forward baste, the centio shwe colving the proble of gaivitu secene to the cable tor oll its lecal station. The combor is alvaye controbler of the Gris, and the otat toae only talkor/ikatosere.

\section{csin-a Protosol}

The "coptentfon" of altipie comboxen for vimulteacous sccese to the coatrol changel is resolved by wee of - Cru-ch protocol (Carrier sade inltiple scsenecolliaion Aroidence). Dafore treneniteing, scobex anoures (by moltories ito "recelve" lival) that wo

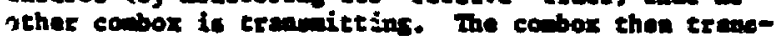

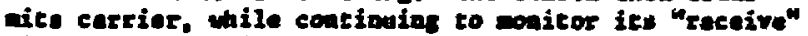
lince, for a period loas enouth to enume thec ite ifall hee propagated to all wodes on tha vetwork; follow ins that, date crencilazion betine and contisues to completine of cho neceage. Fropageton deleya ny enable two cobora "aineleanously" to we a claes chenael, perniteins both to bagin to trancrit certier. mil coadition is cernd a "collialog"; both ccobone will observe the collibion since they are monitoring cheir "recaive" lives. Shen e collition occurs, oas combor will defer, i.e., otop tranenifties; prierity is this meter is deterinined by position on the bus. Aay desired pode on the antwork can be celected to wh the hichest priority wode. The csk-ce protocol gurentes that w collivion vill oceur onen date tranomienfon the begun. I mase aimplification is echieved in collistor datection by the une of two coexial cables and directionsl couplers, oince a combox" ow cerrier is not prosent on its "receire" lises.

\section{Bost}

The host conputer of the MCS control syaten it a PDP-10 running a modified rersion of the enaufacturer's ecadard operatias oraten ros-10. Present eccelerator hardware is rontrolled over bifh speed (0.5 youd) helf-duplax seriel dace linke called Datacon; the Dat scon lines are controlled by a netmrtx of five PDP-B peripheral procensore (PP). The R" are conacted to the host PDP-10 by full duplex high speed (0.5 rbeud) aerial date 1 igks; host comeications with the FF's are supported by a wonitor level prococol it the host. I post-2P compaicintions are etructurod in the for of file trantera. Vaer prorrem ccastruct files to sad to the approprilate pp's; these files concain inseruction to she pij, to preform transection on che Datecen lives. Reauleivl deta obraind by the PF's from eccelerator devices ovall the Datecon libes are assebled inte filas wich cila be receired by weer progreas fion the PF's.

$\Delta$ subec of the Bot-ip file-structured consuiention peotocol hes been utilized, almot unchented, to support commatications betwen the bost and and Gatwey PP wich provides sccese to the setur. in esitional full duplex hiph opoed sorial

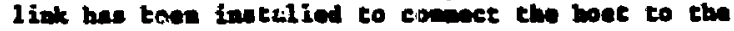
Gateme $\mathbf{F}$.

\section{Cecomer 19}

4 Gaterey $2 P$ has boen ieplenated wites an

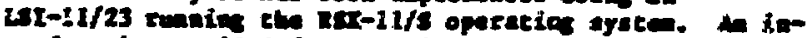

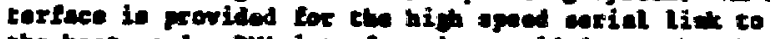
the bot, aw a bu intestece is prorided to nike the $11 / 23$ a calkarfliotenes davies on the Getn. Soch of

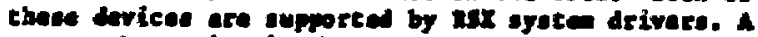

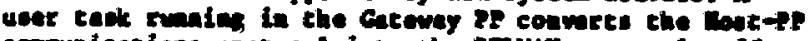
compication protocol into the huma protocol, off-

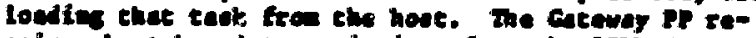

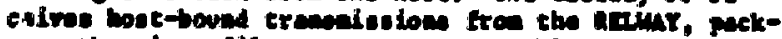

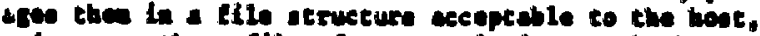
asd quwes thene fites bar trancilooton to the boet is the hoot ohall reywat then.

$$
\text { fiv. "fon }
$$

MunY otetion are contencted frod Intel bourdlevel If-bit meltibu äcroprosescor. preduct, roming

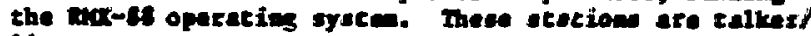

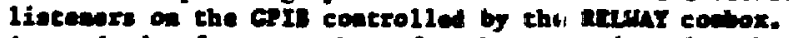

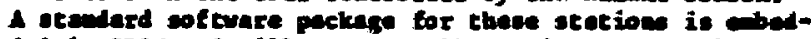

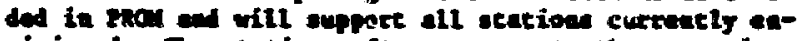

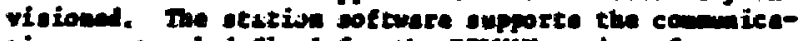
tican protocol defiead for the rutur, an purform operatiow on accelerator harlwere vader ita control eccordins to aruix moseges it seceives. Tho form of tcation cominication vith secalerator harture ere curo

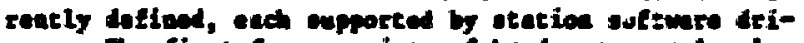
vero. The firet for couldes of hardinere on a loed GIs (diotinet fres the combor Gits) for with the ots"

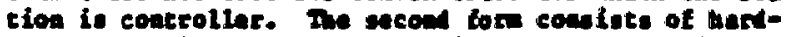

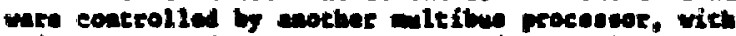

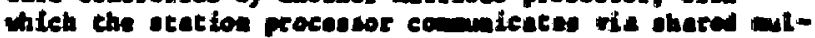
thus nemsy.

Tis ficot pearecion of etecion coftwere upporte bhree caterorite of operation. (1) station can set hardmre to opecificd ateatas and sacpoincs. (2)

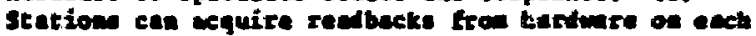

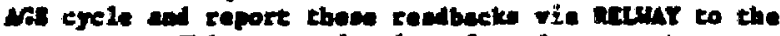
requeter. Itis paration is reforral to it the roport task. As a prectical nuter, the regueter is alweys the bose por-10 comerer vid the cateney PF;

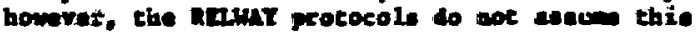
relationh ip and will suppore different host or even

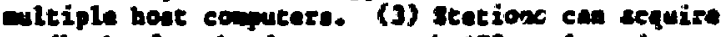

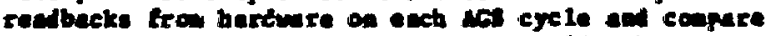
tha radbscke with standard velwet provided by the host, and report deviations fro expeted velues to the han on ex exception besis. Itis operetion is refarted to as the alera task.

\section{netwer comanication Procccola}

The comaication protocdl defied for the

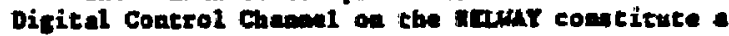
lavered protocol based in opirit upon the Internationel staodarde Organieation (IHO) Opan Byoto Interevanet (OSI) serven isyer well. 2 The prococol will be inplement is e etaged fachion. The conboves inplenat layers 1 and 2 of the Iso/ost ackl. The reminies layers are inpleaneted in the Wont/Gatwoy and in the station. Irere 3, 4, and 5 are suppoted at the prerating syeten lowel, layere 6 and 7 at the weer code level. Catewy support for the lower lawele of the

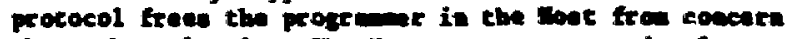

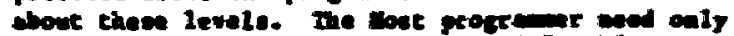
reppect the petocol ac ivels if and 7, wich comeitute

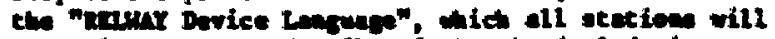
recosaise, and the betails of the physicel devilees mer

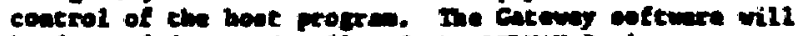

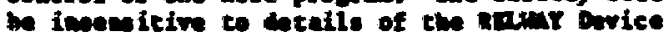
ingrege. 


\section{Suten Mreveres}

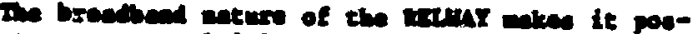
-ible to winct mietple condectertes Digital Cow-

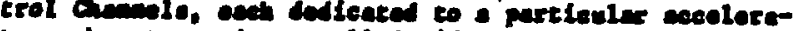

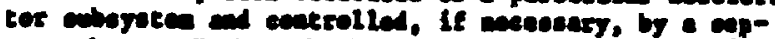

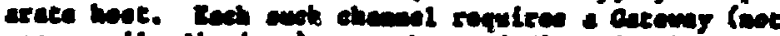

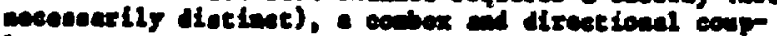
lere.

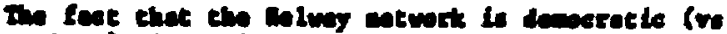

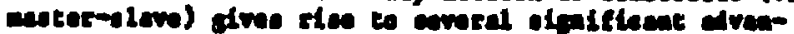

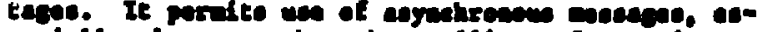

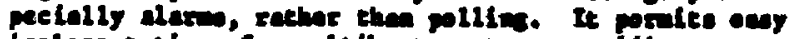

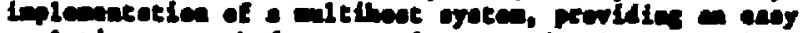

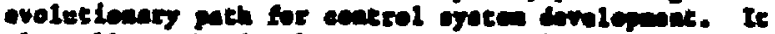

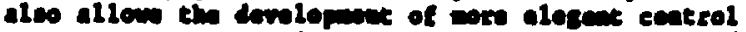

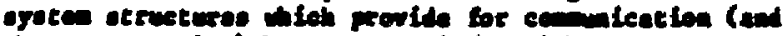

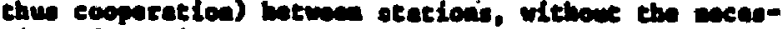

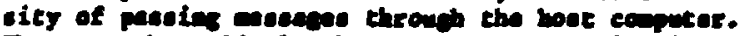
The sotwort could ales be uad a a sommicetion wediu betwe bot eenmetere.

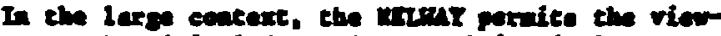
point that the Difitel control Chenel to oibis a GI

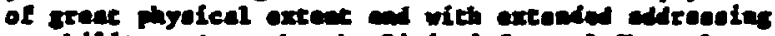
copebility. A weh, the DLitel conerol Guenel enjogre oll che edveateres of the CPIS, enpectelly

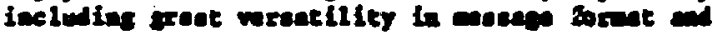
contente (a conpared to the proviowily wad Duteed arote). The otrieture that the Rxun be inplemated

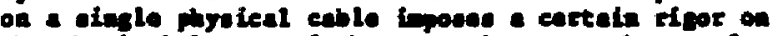
the phraical lovout of the control oretem, we conters the dranterg thet cons with a vifled comeniestion syotec.

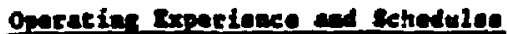

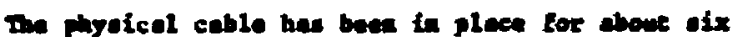
noths, end axtensive tatins of digitel cemaication

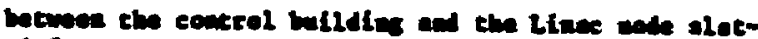
ad Eer coures centrol hom demonstraced the roliobll-

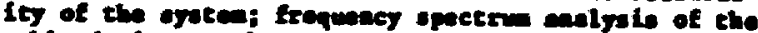

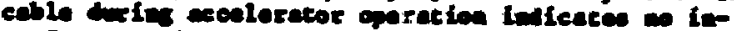

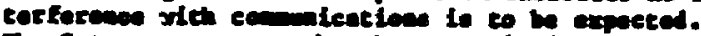

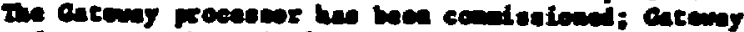

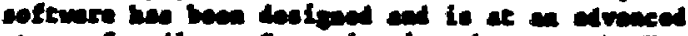

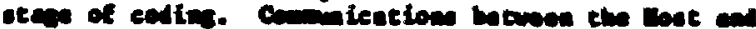

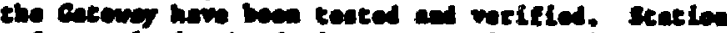

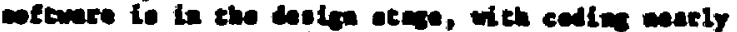

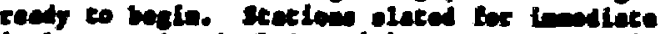

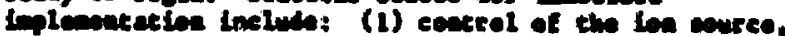

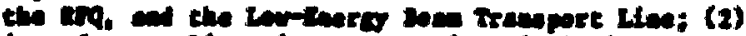

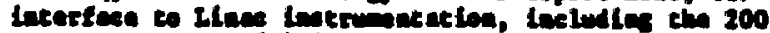

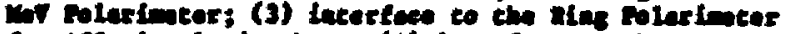

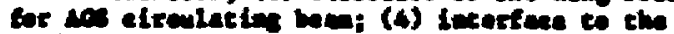

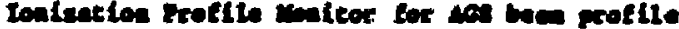

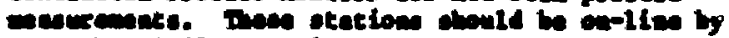
Sopterine 1943. Stetion for control of the Fast

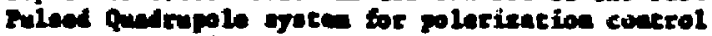
ecross intrinsic raconuces, and control of the fanc Fulead Dipole oyoten for pierization concrol across

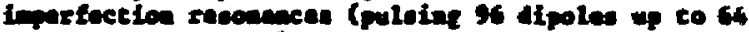

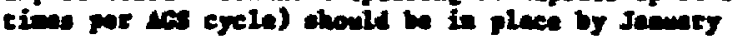
294.

\section{Beferences}

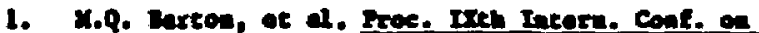

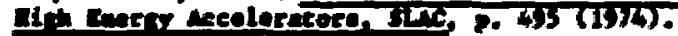

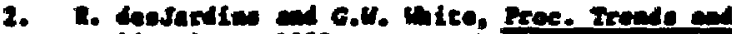

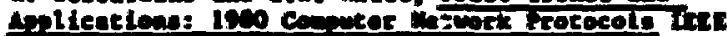

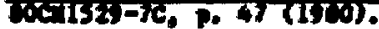

\section{DISCLATMIR}

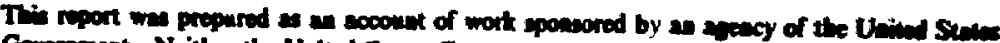

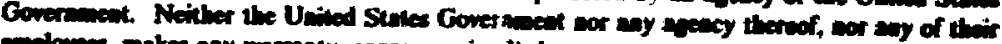

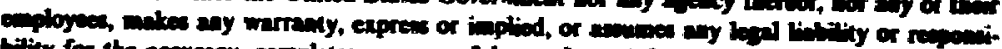

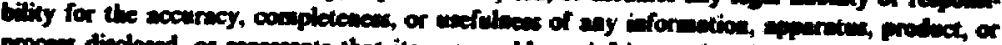

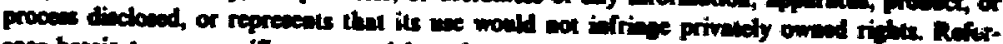

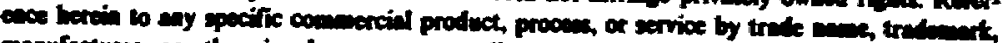

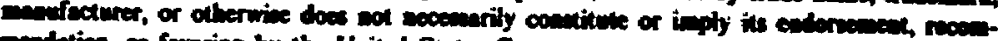

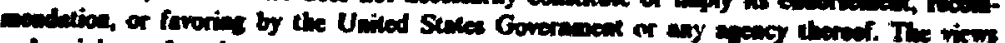

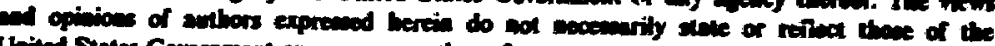
Unined Stence Covernmeit or any suescy thereof, 